\title{
Analysis of Factors Affecting Community on The Use of Non-Cash Payment Tools in Taman District, Sidoarjo Regency
}

\author{
Nurdina $^{1 *}$, R. Bambang Dwi Waryanto ${ }^{2}$, Nurul Afiah ${ }^{3}$ \\ 1,2,3 Akuntansi Universitas PGRI AdiBuana Surabaya \\ e-mail: nurdina@unipasby.ac.id ${ }^{1}$ \\ * Corresponding Author: E-mail: nurdina@unipasby.ac.id
}

\begin{tabular}{ll}
\hline ARTICLE INFO & ABSTRACT \\
\cline { 1 - 2 } $\begin{array}{l}\text { Received June 2021 } \\
\text { Accepted June 2021 } \\
\text { Published July 2021 }\end{array}$ & $\begin{array}{l}\text { The purpose of the study was to examine the effect of perceived } \\
\text { benefits, convenience, trustworthiness, and risk on the use of } \\
\text { non-cash payment instruments in Taman Sub-district, Sidoarjo } \\
\text { Regency. The Theory Acceptance Model (TAM) is used as the } \\
\text { Keywords: } \\
\begin{array}{l}\text { Convenience, Risk, Theory } \\
\text { Acceptance Model, Trust. }\end{array}\end{array}$ \\
$\begin{array}{l}\text { theoretical basis for the research. The research sample is people } \\
\text { who transact at Alfamart, Indomaret, McDonald's Geluran, and } \\
\text { Alfamidi in Taman sub-district, Sidoarjo district. Multilevel } \\
\text { random sampling method. The questionnaires distributed were } \\
\text { 100 respondents. The results showed that trust had no effect, } \\
\text { while the benefits, convenience, and risk had an effect on non- } \\
\text { cash payment instruments. }\end{array}$ \\
\hline
\end{tabular}

\section{Introduction}

Conventional methods such as service to customers directly lead to time inefficient. Science and technology that is growing rapidly today helps reduce the complexity of conventional methods. Human behavior has changed in accessing various information and features of electronic services. Non-cash payment instruments or Financial Technology (FinTech) are part of the latest technology.

Davis (1986) formulated the Technology Acceptance Model (TAM) as one of the most tested models. TAM adapts the theory of reasoned action from Ajzen and Fishbein (1980) regarding the causal relationship of users' internal beliefs, attitudes, intentions, and computer use behavior (Davis et al. 1989). TAM studies are characterized by different methodologies and measurement factors, yielding conflicting and highly variable findings.

TAM aims to make predictions about the acceptance and use of a new information system and adaptability for users (Davis, 1989). TAM explained that there are two factors that influence interest in technology acceptance, namely perceptions of usefulness and perceptions of ease of use. Through the modification and development of TAM theory, it can be understood that users' reactions and perceptions of technology can affect their attitude in accepting the use of technology. There are 4 (four) factors selected for the modification and development of the TAM theory, namely the perceived 
benefit factor, the perceived ease of use, the perception of trust, and the risk perception of the use of non-cash payment instruments.

People feel that the use of a technology will provide usefulness in transactions. Perceived usefulness or benefits defined by Davis (1989) is the level at which users feel confident that by using a technology or system, their performance will increase. Research by Kurniawati et al., (2017) shows that these two perceptions affect the interest in using Mobile Banking.

Perception of ease measures a person's belief in a technology that facilitates business (Davis, 1989). With the ease of using a system, users become more interested in using a system. The perception of convenience indicates that a system is designed not to make it difficult for users, but to make it easier for someone to complete their work (Mulyati, Sugiharto, Dewi, 2020).

Trust is very important in terms of online transactions. In the concept of non-cash payments, the transaction process is well explained and easy to understand, such as for example payment methods, top ups, and transfer methods. This can help build user trust (Flavian and Guinaliu, 2006). Consequences of different user behavior that also arise from their beliefs and concerns about privacy.

In addition to factors that encourage interest in using non-cash payments, there are also factors that reduce interest in using them, one of which is risk perception. Firdayanti (2014) explains that perceived risk is a way for consumers to perceive possible losses that will be obtained from their decisions, due to uncertainty. Perceived risk is considered a negative consequence of uncertainty from the use of a product or service.

The purpose of the study was to examine the effect of perceived benefits, convenience, trust and risk on the use of non-cash payment instruments. This payment instrument is often used for purchasing goods or buying and selling transactions online or offline.

Based on the background and problems above, it is necessary to identify the effect, benefit, convenience, trustworthiness, and risk on the use of non-cash payment instruments in Taman Subdistrict, Sidoarjo Regency. Because most of the people have low interest in the use of these payment instruments.

\section{Research Methods}

- Population, Sample, and Sampling Technique

The research population is people who live in the Taman District, Sidoarjo Regency. The sample used is the people who transact at Alfamart, Indomaret, McDonald's Geluran, and Alfamidi in Taman sub- district, Sidoarjo district with a total of 100 respondents. Sampling technique with stratified random sampling technique.

- Types, Data Sources \& Data Collection Techniques

This research is quantitative. The data source is primary data, that is, questionnaires were given manually at Alfamart, Indomaret, McDonald's Geluran, and Alfamidi, Taman sub-district, Sidoarjo district. The technique of collecting data is a questionnaire which is calculated using an interval scale.

- Data analysis technique 
The data analysis techniques are validity and reliability tests, classical assumption tests (normality test, multicollinearity, and heteroscedasticity), multiple linear regression analysis, hypothesis testing on $\mathrm{R} 2$, F test and t test.

\section{Result and Discussion}

Theoretical basis and hypotheses development: Technology Acceptance Model (TAM):TAM is a research model conducted to analyze the factors that influence the acceptance of the use of information technology. TAM was first introduced by Fred D. Davis in 1986, made specifically to model the effect of acceptance (acceptance) felt by users of an information technology. According to Davis (1989), the main purpose of TAM is to provide a reference for analyzing external influences in the form of trust, intention, and user goals. TAM illustrates that there are two dominant factors that influence the acceptance of information technology, namely, first, user perceptions of perceived benefits and second, perceived ease of use of information technology. These two factors will affect the user's desire or intention to use information technology. The TAM model was adopted from Theory of Reasoned Action (TRA), which was first introduced by Martin Fishbein and Ajzen in 1980. This theory links beliefs, attitudes, intentions and behavior. Interest is the main predictor of user behavior.

Although one can make decisions based on other reasons, but the main concept in this theory is to focus on paying attention and considering something that is considered important by the user.

Theory of Reasoned Action: Theory Reasoned Action (TRA) was presented by Ajzen and Fishbein. This theory assumes that human behavior consciously considers the various available information. Behavioral beliefs become the underlying influence of a person's attitude towards behavioral performance (Madden et al., 1992). This TRA theory connects beliefs, attitudes, intentions, and behavior. Intentions encourage individuals to share attitudes and interests toward behavior (for example, positive or negative evaluation of a person when performing a behavior) and by subjective norms (ie, perceived social pressure to behave or not) (Liao et al, 2010).

Theory of Planned Behavior: In studying human behavior, there are several theories used, one of which is the Theory of planned behavior. Azjen (1991) explains that TPB is an individual's intention to perform a certain behavior. TPB theory extends TRA by adding a construct of behavioral control perception to eliminate the limitations of TRA when dealing with the behavior of individuals who do not have full control over a will. Azjen (1991) in his research explains that TPB reveals three independent determinants of conceptual intention. The first is attitude, the second is subjective norm, and the third is perceived behavioral control. The difference between TRA and TPB lies in the addition of behavioral intentions. Perceptions of behavioral control indicate that individual motivation is influenced by perceptions of the level of difficulty or ease (Akhmad, 2010).

Effect of Perception of Ease on the use of non-cash payment instruments: Perception of convenience means the belief that using an information technology system does not require great effort (free of effort) (Yani et al., 2018). Davis (1989) provides 
indicators to measure perceived ease of use in information technology including: 1) Very easy to use; 2) Very easy to learn; 3)Easy to be skilled; 4) Controllable; 5) Clear \& easy to understand; 6) Provide convenience for users. Wildan (2019) concludes that the perception of convenience has a positive effect on the interest in transacting with Fintech.

H1: Ease has a positive effect on the use of non-cash payment instruments.

The Influence of Perceived Benefits on the Use of Non-Cash Payment Instruments alat Benefit as a person's level of belief that the use of certain subjects will improve work performance. Indicators to measure perceived usefulness: 1) Useful; 2) Make work easier; 3) Speed up work; 4) Improve performance; 5) Increase productivity; 6) Increase the success produced by a person with the goals to be achieved (Davis, 1989). The research of Kumar et al. (2017) stated that perceived benefits are a factor that significantly influences interest in using Mobile Banking services.

$\mathrm{H} 2$ : Benefit has a positive effect on the use of non-cash payment instruments.

Effect of Trust on the use of non-cash payment instruments: Research by Maroofi et al (2013) proves that trust is the key to perceived ease of using Mobile Banking services. Davis (1989) provides indicators to measure trust in the use of information technology including: 1) Do not believe; 2) Trustworthy; 3) Safeguard interests; 4) Information provided; 5) Tendency to trust; 6) Trusting is not difficult; 7) Security; 8) Trust.

H3 : The trust factor has a positive effect on the use of non-cash payment instruments.

Effect of Risk on the use of non-cash payment instruments: Research by Lafraxo et al. (2018) which shows that risk perception has no effect on interest in using Mobile Banking. The research of Priambodo and Prabawani (2016) shows that Risk Perception has a negative effect on the interest in using electronic money services in the people of the city of Semarang. The lower the user's perceived risk, the higher the interest in using the service. Conversely, if the perception of risk is higher, it will reduce interest in using non-cash payment services. Davis (1989) provides indicators to measure the perceived risk of using information technology including: 1) There are certain risks; 2) Incurring losses; 3) The thought that it is risky.

$\mathrm{H} 4$ : Risk has a negative effect on the use of non-cash payment instruments.

- Validity test

The results of this test have $r$ arithmetic $>r$ table with $N=100$ of $0.195 \&$ sig value $<5 \%$. So all statement items have valid status and can be used in data collection (Sugiyono, 2017).

- Reliability Test

The results of the Cronbach Alpha value in the benefit variable are 0.671, convenience is 0.799 , risk is 0.828 , trust is 0.627 , using non-cash payment instruments is 0.749. From the five variables, it was concluded that the Cronbach Alpha value was $>$ 0.60. Sugiyono, 2017 shows that Cronbach's Alpha is acceptable, if $>0.60$, then each question in the questionnaire is declared reliable. 
Table 1 Cronbach Alpha - Reliability Test Results

\begin{tabular}{cc}
\hline Variable & Cronbach Alpha \\
\hline Benefit (X1) & 0,671 \\
Convenience (X2) & 0,799 \\
Risk (X3) & 0,828 \\
Trust (X4) & 0,627 \\
Use of Non-Cash Payment Instruments & $0,749(\mathrm{Y})$ \\
\hline
\end{tabular}

(Source : SPSS data processing, 2021)

- Normality Test

The results of the Kolmogorov-Smirnov Normality Test have a sig value of 0.623 (>5\%), meaning that the data is normally distributed (Ghozali, 2018).

Table 2 Kolmogorov Smirnov - Normality Test Results

\begin{tabular}{cccc}
\hline Variable & $\mathrm{N}$ & Sig value. & Information \\
\hline Unstandardized Residual & 100 & 0,623 & Normal \\
\hline
\end{tabular}

(Source : SPSS data processing, 2021)

- Multicollinearity Test

The tolerance value for the benefit variable is $0.274>0.10$, the convenience is 0.343 $>0.10$, the confidence is $0.492>0.10$, and the risk is $0.724>0.10$. For the value of VIF, the benefit variable is $3.646<0.10$, the convenience is $2.916<0.10$, the confidence is $2.033<$ 0.10 , and the risk is $1.382<0.10$. If the tolerance value is $>0.10$ and the VIF value is $<10$, then there is no multicollinearity between the independent variables in the regression model (Sugiyono, 2017).

Table 3 Multicollinearity Test Results

\begin{tabular}{lccl}
\hline \multicolumn{1}{c}{ Variabel } & Tolerance & VIF & Information \\
\hline Benefit & 0,274 & 3,646 & There is no multikolinearitas \\
Convenience & 0,343 & 2,916 & There is no multikolinearitas \\
Risk & 0,724 & 1,382 & There is no multikolinearitas \\
Trust & 0,492 & 2,033 & There is no multikolinearitas \\
\hline
\end{tabular}

(Source : SPSS data processing, 2021)

- Heteroscedasticity Test

The results of the sig values of the four variables showed sig $>0.05$, it was concluded that there were no symptoms of heteroscedasticity (Ghozali, 2018).

Table 4 Heteroscedasticity Test Results

\begin{tabular}{lccc}
\hline \multicolumn{1}{c}{ Variable } & Sig & Critical Value & Information \\
\hline Benefit & 0,276 & 0,05 & There is no heteroscedasticity \\
Convenience & 0,125 & 0,05 & There is no heteroscedasticity \\
Risk & 0,102 & 0,05 & There is no heteroscedasticity \\
Trust & 0,287 & 0,05 & There is no heteroscedasticity \\
\hline
\end{tabular}

(Source : SPSS data processing, 2021)

- Multiple Linear Regression Analysis

The results of the regression analysis test that benefit, convenience, risk affect the use of non- cash payment instruments, while trust has no effect. 
Table 5 Multiple Linear Regression Analysis Test Results Coefficients ${ }^{a}$

\begin{tabular}{|c|c|c|c|c|c|}
\hline \multirow[t]{2}{*}{ Model } & \multicolumn{2}{|c|}{ Unstandardized Coefficients } & \multirow{2}{*}{$\begin{array}{c}\begin{array}{c}\text { Standardized } \\
\text { Coefficients }\end{array} \\
\text { Beta }\end{array}$} & \multirow[t]{2}{*}{$\mathrm{t}$} & \multirow[t]{2}{*}{ Sig. } \\
\hline & $B$ & Std. Error & & & \\
\hline (Constant) & 1,694 & 1,268 & & 1,336 & 185 \\
\hline Benefit & ,089 & ,087 & 131 & 1,018 & ,001 \\
\hline 1 Convenience & 318 & ,064 & ,572 & 4,938 & ,000 \\
\hline Risk &,- 115 & ,046 & -,195 & $-2,476$ & ,015 \\
\hline Trust & ,046 & ,050 & 087 & ,917 & 361 \\
\hline
\end{tabular}

(Source : SPSS data processing, 2021)

a. Dependent Variable: use of non-cash payment instruments

$$
\mathrm{Y}=1,694+0,089 \mathrm{X} 1+0,318 \mathrm{X} 2-0,115 \mathrm{X} 3+0,046 \mathrm{X} 4+\mathrm{e}
$$

- Coefficient of Determination ( R2 )

Table $6 \mathrm{R}^{2}$ Test

\begin{tabular}{ccc}
\hline $\mathbf{R}$ & $\mathbf{R}^{2}$ & Adjusted $\mathbf{R}^{2}$ \\
\hline 0,757 & 0,572 & 0,554 \\
\hline \multicolumn{4}{l}{ (Source : SPSS data processing, 2021 ) }
\end{tabular}

The result of Adjusted R2 is 0.554, meaning that the effect of the independent variable on the dependent variable is 0.554 , meaning that the dependent variable is $55.4 \%$. The remaining $44.6 \%$ is explained by other variables not included in this study.

- Model Test (F Test).

Table 7 F Test Result

\begin{tabular}{cccc}
\hline Dependent Variable & F Count & Sig & Information \\
\hline $\mathrm{Y}$ & 31,790 & 0,000 & Significant \\
\hline
\end{tabular}

(Source : SPSS data processing, 2021)

The results of the $F$ test found that the sig value was 0.000 or had a value of $<5 \%$, so it was concluded that there was an effect of the independent variables together on the dependent variable.

Table 8 T Test Results

Dependent Variable: Use of Non-Cash Payment Instruments

\begin{tabular}{lcccc}
\hline $\begin{array}{c}\text { Independent } \\
\text { Variable }\end{array}$ & Coefficient & T Hitung & Sig & Conclusion \\
\hline Benefit & 0,089 & 1,018 & 0,001 & H1 : Supported \\
Convenience & 0,318 & 4,938 & 0,000 & H2 : Supported \\
Risk & $-0,115$ & $-2,476$ & 0,015 & H3 : Supported \\
Trust & 0,046 & 0,917 & 0,361 & H4 : Not supported \\
\hline
\end{tabular}

(Source : SPSS data processing, 2021)

The results of the t-test above obtain a t-count of usefulness of 1.018 and a sig value of benefit of 0.001 . Ease has a tcount value of 4.938 and a sig value of 0.000 . The risk has a tcount of -2.476 and the sig value of the risk variable is 0.015 . The confidence 
value of tcount is 0.917 and the sig value of the confidence variable is 0.361 . The four sig values (sig $<5 \%$ and sig $>5 \%$ ) can be concluded that benefit, convenience, and risk have a sig effect on the use of non-cash payment instruments. While trust has no effect.

- Benefit has a positive effect on the use of non-cash payment instruments.

Perceived usefulness defined by Davis (1989) is the level at which users feel confident that by using a technology or system, their performance will increase. The benefits that can be obtained include time savings, cost savings, and can increase efficiency and effectiveness in transactions. These results are consistent with research conducted by Kumar (2017) and Leiva (2016) which state that perceived usefulness has a positive influence on interest in using Jenius Mobile banking.

- Convenience has a positive effect on the use of non-cash payment instruments.

Convenience has a positive effect on the use of non-cash payment instruments. Statistical results show that the unstandardized coefficient value is 0.318 and the sig value is 0.000 . People believe in the use of non-cash payment instruments because their use is easy and not difficult to understand. Research by Wibowo and Rosmauli (2015); Utami and Kusumawati (2017) reveal that the perception of convenience has a significant positive effect on the interest in using e-money.

- Trust has no effect on the use of non-cash payment instruments

Statistical results show that the unstandardized coefficient value is 0.046 and the sig value is 0.361 . Trust has no effect on the use of non-cash payment instruments. Digital transactions contain great uncertainty and risk. This condition reduces the level of public confidence in the use of this payment instrument. Research by Octavia and Hafizh (2019) states that trust has no significant effect on consumers regarding e-payments.

- The risk of negatively affecting the use of non-cash payment instruments

Risk is something that is uncertain and can occur during the transaction process. Security factors and disturbances that occur during the online-based transaction process become a negative influence on system users. Someone will certainly use a system that is safe and free from risk. The risks that consumers worry about will reduce their interest in using and conducting transactions. Research by Al-Jabri (2015) and Prabawani (2017) states that risk has a significant negative effect on interest in using e-money.

\section{Conclusion}

Benefit, convenience, and risk affect the use of non-cash payment instruments. This happens because people feel that the benefits they get are more, including being more efficient, guaranteed security, minimizing crime, and having lots of discounts. The higher the usefulness and convenience, the greater the user's desire to use it. The lower the user's risk, the interest in using non-cash payment instruments will increase, on the contrary if the user's risk is higher, the interest in using it will decrease. Risks and new information technology have caused not all people to trust non-cash payment instruments. Therefore, further researchers are advised to add other variables that have an influence on the use of non-cash payment instruments, such as technological innovation, promotional attractiveness, user age. 


\section{References}

[1] Achmat, Z. (2010). Theory of Planned Behavior, Masihkan Relevan. http://zakarija. staff. umm. ac. id/files/20, 10, p.12.

[2] Ajzen, I. and Fishbein, M.A. (1980). Understanding Attitudes and Predicting Social Behavior.

[3] Prentice Hall Inc. Englewood Cliffs. NJ.

[4] Ajzen, Icek. (1991). The Theory of Planned Behaviour. Organizational Behaviour and Human Decision Process, 50, 179-2011.

[5] Hanif Astika Kurniawati, Wahyu Agus Winarno, Alfi Arif. (2017). Analisis Minat Penggunaan Mobile Banking Dengan Pendekatan Technology Acceptance Model (TAM) Yang Telah Dimodifikasi. e- Journal Ekonomi Bisnis dan Akuntansi, 4(1),24-29.

[6] Carlos Flavian and Miguel Guinalıu.(2006). Consumer trust, perceived security and privacy policy three basic elements of loyalty to a web site. Industrial Management \& Data Systems, 106(5), 601-620.

[7] Davis,F. (1986). A technology acceptance model for empirically testing new enduser information systems: theory and results. Doctoral dissertation. MIT Sloan School of Management. Cambridge. MA.

[8] Davis, F.D. (1989). Perceived usefulness, perceived ease of use, and user acceptance of information technology. MIS Quarterly, 13 (3), 319-340.

[9] Firdayanti, R. (2014). Persepsi Risiko Melakukan E-Commerce dengan Kepercayaan Konsumen dalam Membeli Produk Fashion Online. Journal of Social and Industrial Psychology, 2(4),1-12.

[10] Ghozali, I. (2018). Aplikasi analisis multivariate dengan program IBM SPSS 25. Semarang: Badan penerbit universitas Diponegoro.

[11] I.M., Al-Jabri. (2015). The Intention to use Mobile Banking: Further evidence from Saudi arabia. Departmen of accounting and MIS, College of Industrial.

Management, King Fahd University.

[12] Kumar, V.V. Ravi., Lall, Anurag., Mane, Tanmay. (2017). Extending The TAM Model: Intension Of Manajement Student to Use Mobile Banking: Evidence From India. Global Bussiness Review, 238- 249.

[13] Lafraxo, Y., Hadri, F., Amhal, H. and Rossafi, A. (2018).The Effect of Trust, Perceived Risk and Security on the Adoption of Mobile Banking in Morocco. DOI: 10.5220/0006675604970502 In Proceedings of the 20th International Conference on Enterprise Information Systems (ICEIS 2018), 497-502.

[14] Liao, C., Lin, H.N. and Liu, Y.P. (2010). Predicting the use of pirated software: A contingency model integrating perceived risk with the theory of planned behavior. Journal of Business Ethics, 91(2), 237-252.

[15] Madden, T. J., Ellen, P. S., \& Ajzen, I. (1992). A Comparison of the Theory of Planned Behavior and the Theory of Reasoned Action. Personality and Social Psychology Bulletin, 18(1), 3-9. doi:10.1177/0146167292181001 DOI : ttps://doi.org/10.1177/0146167292181001. 
[16] Maroofi, Fakhraddin., Fatemeh, K., Dehghani, M,. (2013). An Investigation of Initial Trust on Mobile Banking. International Journal of Academic Research In Business and Social Sciences. 3(9).

[17] Mulyati, Bambang Sugiharto, Prini Nurtina Dewi. (2020). Perceptions Of Usefulness And Perceptions Of Easiness To Employees Interest In Using Fintech. Accounting Research Journal of Sutaatmadja (ACCRUALS). 4(2), 244-252. DOI : https://doi.org/10.35310/accruals.v4i02.611.

[18] Octavia, D., \& Hafizh, M. D. (2019). Faktor -Faktor Yang Mempengaruhi Persepsi Konsumen E- payment(Studi Kasus: Pengguna Kartu Kredit dan Debit di Kota Bandung). Jurnal Manajemen Indonesia. Online ISSN: 2502-3713. Print ISSN: 14117835.Universitas Telkom,19(1), 1-9. https://doi.org/10.25124/jmi.v19i1.1980.

[19] Prabawani, P. (2017). pengaruh manfaat, kemudahan penggunaan, dan risiko terhadap minat menggunakan layanan uang elektronik (studi kasus pada masyarakat di kota semarang). jurnal administrasi bisnis, 1-9.

[20] Sugiyono. (2017). Statistika untuk penelitian . Bandung: Alfabeta.

[21] S. Priambodo, and B. Prabawani.(2016).Pengaruh Persepsi Manfaat, Persepsi Kemudahan Penggunan, Dan Persepsi Risiko Terhadap Minat Menggunakan Layanan Uang Elektronik (Studi Kasus pada Masyarakat di Kota Semarang). Jurnal Ilmu Administrasi Bisnis, 5(2), 127-135.

[22] Utami, S., \& Kusumawati. (2017).Faktor-Faktor yang Mempengaruhi Minat Menggunakan E-money.Jurnal Balance,14(2).

[23] Wibowo, S., \& Rosmauli, D. (2015). Pengaruh Persepsi Manfaat, Persepsi Kemudahan, Fitur Layanan, dan Kepercayaan Terhadap Minat Menggunakan emoney Card. Jurnal Riset Manajemen Sains Indonesia, 6(1).

[24] Wildan, Muhammad (2019) Pengaruh Persepsi Kemudahan Penggunaan, Efektivitas Dan Risiko Terhadap Minat Bertransaksi Menggunakan Financial Technology (Fintech). Skripsi. UIN Walisongo Semarang.

[25] Yani, E., Lestari, A. F., Amalia, H., Puspita, A. (2018). Pengaruh Internet Banking Terhadap Minat Nasabah Dalam Bertransaksi Dengan Technology Acceptance Model. Jurnal Informatika. 5 (1). 34-42. 